\title{
Effect of Spraying Salicylic Acid on Fruiting of Valencia Orange Trees
}

\author{
Randa El- Sayed Youness Habasy \\ Citriculture Dept. Hort. Res. Inst. ARC, Giza, Egypt \\ E.mail: Faissalfadel@yahoo.com
}

Received on: 8/7/2015

Accepted: 6/9/2015

\begin{abstract}
Growth characters, tree nutritional status, fruit set \%, June drop \%, yield and fruit quality of Valencia orange trees in response to spraying salicylic acid at 0.0 to $400 \mathrm{ppm}$ either applied once at growth start or twice at growth start and again just after fruit setting were investigated during 2012 /2013 and 2013/ 2014 seasons.

Spraying salicylic acid at 100 to $400 \mathrm{ppm}$ once or twice considerably improved all growth characters, leaf pigments, $\mathrm{N}, \mathrm{P}, \mathrm{K}, \mathrm{Mg}$ and Ca percentages, initial fruit set $\%$, fruit retention $\%$, yield and fruit quality over the check treatment. All salicylic acid treatments effectively reduced June drop. Using salicylic acid at $400 \mathrm{ppm}$ once or twice caused a significant reduction on all the aforementioned parameters comparing with using salicylic acid at 100 to $200 \mathrm{ppm}$. Two sprays of salicylic acid were preferable than using it once in this connection.

Treating Valencia orange trees twice at growth start and just after fruit set with salicylic acid at $200 \mathrm{ppm}$ was responsible for promoting yield and fruit quality.
\end{abstract}

Key words: Salicylic acid, growth, fruiting, Valencia orange trees.

\section{INTRODUCTION}

Recently, many trials were accomplished for promoting yield and fruit quality of Valencia orange trees grown successfully under Middle Egypt conditions by using non- traditional horticultural practices such as application of salicylic acid. Ding et al., (2001); Ding and Wang (2003) and Hayat and Ahmed (2007) found that salicylic acid was responsible for protecting the plants from all stresses and retarding reactive oxygen forms that destroyed the plant cells. They found that treating the trees with salicylic acid was very effective in enhancing metabolism of plants and the biosynthesis of all organic food. Using salicylic acid at 50 to 400 ppm once, twice, or three times was very effective in improving growth, yield and fruit quality in most evergreen fruit crops (Ahmed, 2011; Abd ElRahman and El- Masry, 2012; Ahmed et al., 2014 and 2015a \& b, Omar, 2015 and Abd El- Mageed, 2015).

The target of this study was examining the impact of spraying different concentrations and frequencies of salicylic acid on growth, tree nutritional status, fruit set $\%$, June fruit drop $\%$, yield and fruit quality of Valencia orange trees.

Recently, many trials were accomplished for promoting yield and fruit quality of Valencia orange trees grown successfully under Middle Egypt conditions by using non- traditional horticultural practices such as application of salicylic acid. Ding et al., (2001); Ding and Wang (2003) and Hayat and Ahmed (2007) found that salicylic acid was responsible for protecting the plants from all stresses and retarding reactive oxygen forms that destroyed the plant cells. They found that treating the trees with salicylic acid was very effective in enhancing metabolism of plants and the biosynthesis of all organic food. Using salicylic acid at 50 to 400 ppm once, twice, or three times was very effective in improving growth, yield and fruit quality in most evergreen fruit crops (Ahmed, 2011; Abd ElRahman and El- Masry, 2012; Ahmed et al., 2014 and 2015a \& b, Omar, 2015 and Abd El- Mageed, 2015).

The target of this study was examining the impact of spraying different concentrations and frequencies of salicylic acid on growth, tree nutritional status, fruit set $\%$, June fruit drop $\%$, yield and fruit quality of Valencia orange trees.

\section{MATERIALS AND METHODS}

This study was carried out during 2012/ 2013 and 2013/ 2014 seasons on twenty one uniform and similar in vigour 15- years old Valencia orange trees onto sour orange rootstock. The selected trees were grown in a private citrus orchard located at Abo Saleh Island near Bany Suef city, Bany Suef governorate. The trees were planted at $6 \times 6$ meters apart. The texture of the soil was silty clay with a water table not less than two meters deep. Surface irrigation system was carried out using Nile water. The selected trees were subjected to the normal horticultural practices that already applied in the orchard.

This experiment included the following seven treatments:

1-Control (untreated trees). 
2-Spraying salicylic acid at $100 \mathrm{ppm}$ once at growth start ( $1^{\text {st }}$ week of Mar.)

3-Spraying salicylic acid at $200 \mathrm{ppm}$ once at growth start ( $1^{\text {st }}$ week of Mar.)

4-Spraying salicylic acid at $400 \mathrm{ppm}$ once at growth start ( $1^{\text {st }}$ week of Mar.)

5-Spraying salicylic acid at $100 \mathrm{ppm}$ twice at growth start ( $1^{\text {st }}$ week of Mar.) and again just after fruit set ( $1^{\text {st }}$ week of May).

6-Spraying salicylic acid at $200 \mathrm{ppm}$ twice as mentioned in treatment 5 .

7-Spraying salicylic acid at $400 \mathrm{ppm}$ twice as mentioned in treatment 5 .

Each treatment was replicated three times, one tree per each. The assigned amounts of salicylic acid were solubilized in ethyl alcohol and $\mathrm{pH}$ of the solution was adjusted to 6.0 by using $1.0 \mathrm{~N}$ sodium hydroxide. Triton $\mathrm{B}$ as a wetting agent at $0.05 \%$ was added to all salicylic acid solutions. Randomized complete block design was followed.

During both seasons, the following measurements were carried out.

1-Some vegetative growth characters namely shoot length $(\mathrm{cm})$, shoot thickness $(\mathrm{cm})$ and leaf area $(\mathrm{cm})^{2}$ (Ahmed and Morsy, 1999) in the Spring growth cycle.

2-Leaf pigments namely chlorophylls a \& b, total chlorophylls and total carotenoids (as mg/ $100 \mathrm{~g}$ F.W.) (Hiscox and Isralstam, 1979).

3-Percentages of $\mathrm{N}, \mathrm{P}, \mathrm{K}, \mathrm{Mg}$ and $\mathrm{Ca}$ in the leaves of non fruiting shoots in the spring growth cycle (Summer, 1985 and Wilde et al., 1985).

4-Percentages of initial fruit setting, June fruit dropping and fruit retention

5-Yield expressed in weight / tree (kg.) and number of fruits / tree.

6-Physical characters of the fruits namely weight (g.), volume $\left(\mathrm{cm}^{3}\right)$, height and diameter $(\mathrm{cm})$ of fruit, percentages of fruit peel weight and pulp and fruit peel thickness $(\mathrm{cm})$.

7-Chemical characteristics of the fruits namely T.S.S. \%, total acidity \% ( as g citric acid/ 100 $\mathrm{ml}$ juice., total and reducing sugars $\%$ and vitamin C ( as mg / $100 \mathrm{ml}$ juice, (Lane and Eynon 1965 and A.O.A.C., 2000).

Statistical analysis was done using new L.S.D. at 5\% for making all comparisons among the seven treatments means (Mead et al., 1993).

\section{RESULTS AND DISCUSSION.}

\section{1- Growth characters:}

Data in Table(1) revealed that spraying salicylic acid at 100 to $400 \mathrm{ppm}$ once at growth start or twice at growth start and just after fruit set significantly stimulated shoot length and thickness and leaf area relative to the control treatment. The promotion was significantly associated with increasing concentrations from 0.0 to $200 \mathrm{ppm}$. A significant reduction on such three growth characters was observed with increasing concentration from 200 to $400 \mathrm{ppm}$. Carrying out two sprays of salicylic acid at 100 to $400 \mathrm{ppm}$ was significantly superior than using it once in stimulating all growth characters The maximum values were recorded on the trees that received two sprays of salicylic acid at 200 ppm. The vice versa was obtained on untreated trees. These results were true during both seasons.

\section{2- Pigments and nutrients in the leaves:}

It is clear form the obtained data in Tables $(1 \&$ 2) that chlorophylls a \& b, total chlorophylls, total carotenoids as well as percentages of $\mathrm{N}, \mathrm{P}, \mathrm{K}, \mathrm{Mg}$ and $\mathrm{Ca}$ in the leaves were significantly enhanced in response to foliar application of salicylic acid at 100 to $400 \mathrm{ppm}$ once or twice rather than the check treatment. There was a gradual and significant promotion on these plant pigments and nutrients with increasing concentrations from 0.0 to $200 \mathrm{ppm}$. Increasing concentration from 200 to $400 \mathrm{ppm}$ caused a significant reduction in these values. Two applications of salicylic acid at the named concentrations significantly enhanced these plant pigments and nutrients rather than using one spray. Treating Valencia orange trees twice with salicylic acid at $200 \mathrm{ppm}$ gave the greatest values. The lowest values were recorded on untreated trees. These results were true during both seasons.

3- Percentages of initial fruit setting, fruit retention and June drop.

It is noticed from the data in Table (3) that carrying out one or two sprays of salicylic acid at 100 to $400 \mathrm{ppm}$ significantly was accompanied with improving the percentages of initial fruit set and fruit retention and reducing the percentage of June drop over the check treatment. The effect was significantly depended on increasing concentrations from 0.0 to $200 \mathrm{ppm}$. Using salicylic acid at 400 ppm was significantly associated with reducing percentages of initial fruit set and fruit retention and increasing the percentages of June drop over the application of salicylic acid at 100 to $200 \mathrm{ppm}$. Application of salicylic acid twice at the prementioned concentrations significantly was preferable than using it once in improving initial fruit set and fruit retention and reducing June drop. A significant reduction on initial fruit set and fruit retention and promotion in June drop were observed with increasing salicylic acid concentration from 200 to $400 \mathrm{ppm}$ regardless the frequencies of application. The maximum values of initial fruit set $(6.3 \& 6.9 \%)$, and fruit retention $(1.38 \& 1.39 \%)$ were recorded on the trees that received two sprays of salicylic acid at $200 \mathrm{ppm}$. Under such promised treatment, the lowest June drop values $(0.5$ and 1.0 $\%)$ were recorded. The untreated trees produced the lowest values of initial fruit set $(2.7 \& 3.8 \%)$ and fruit retention 


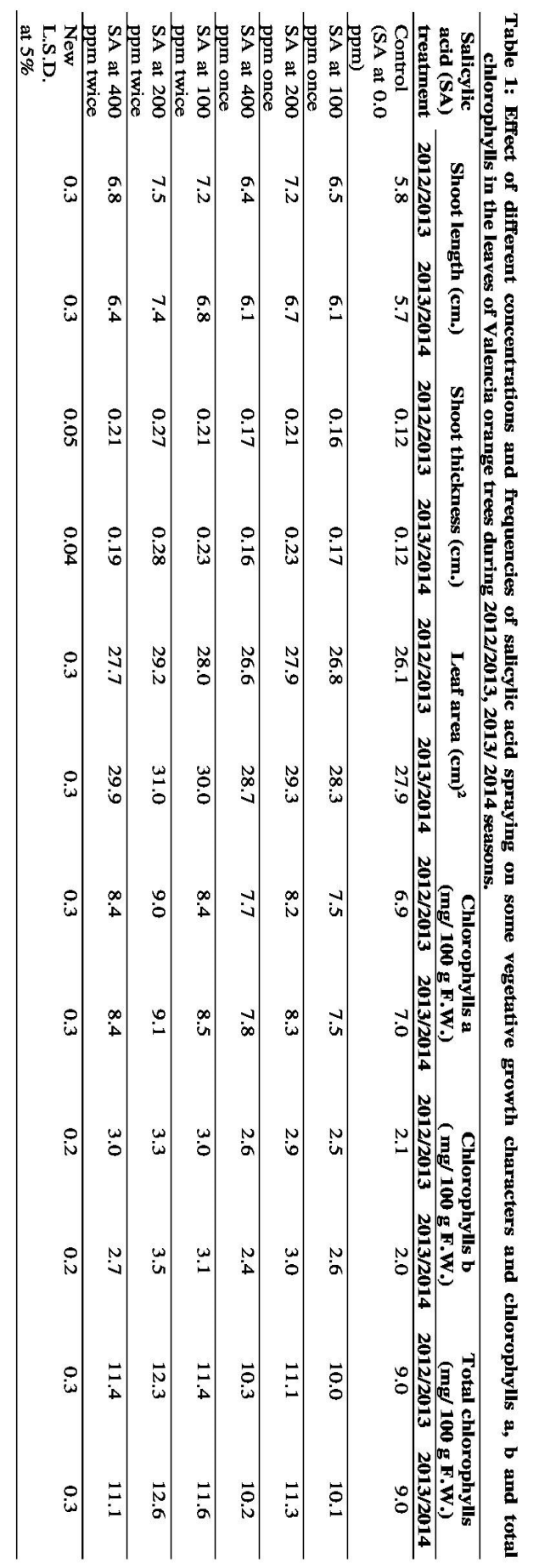




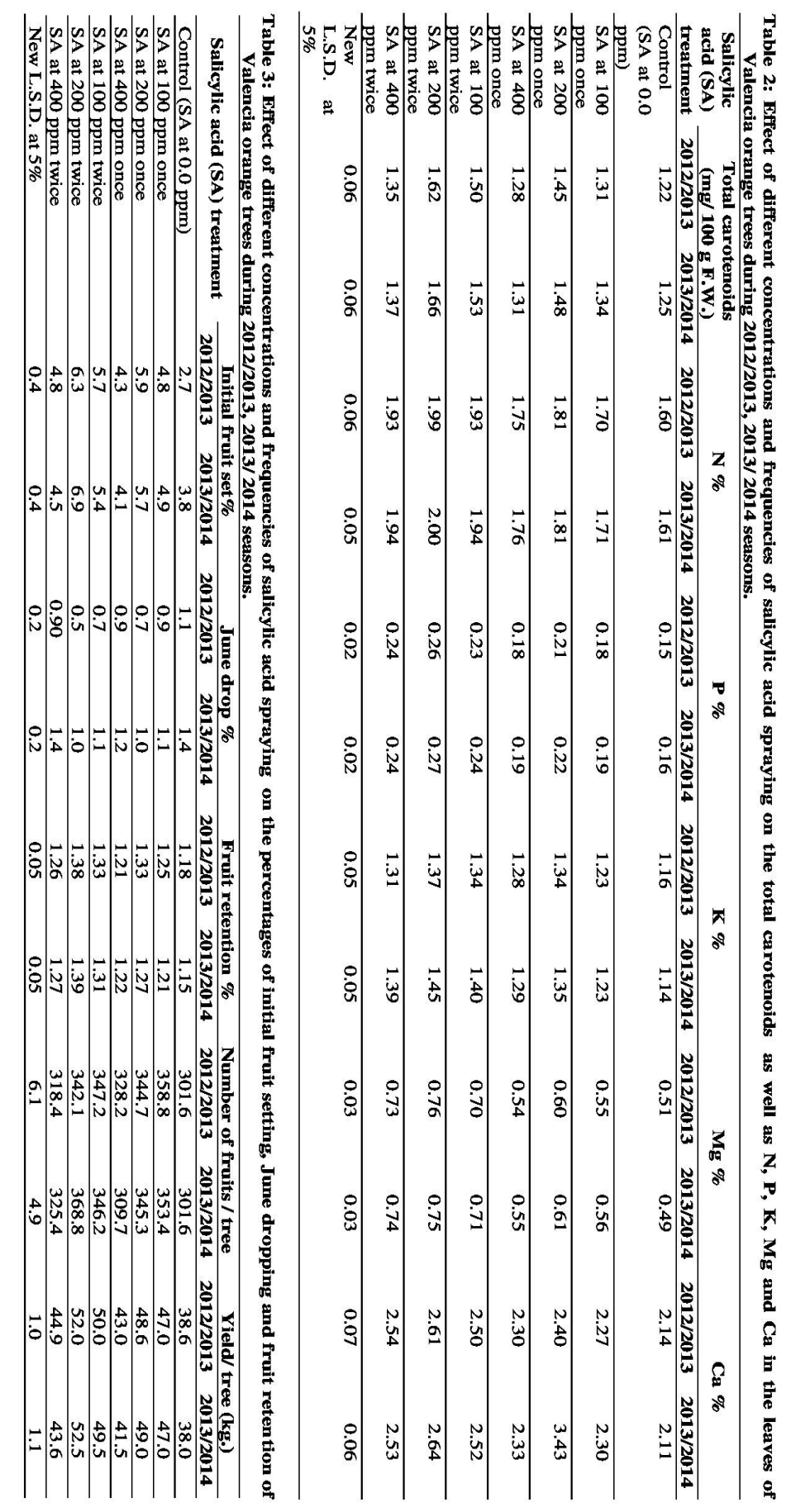




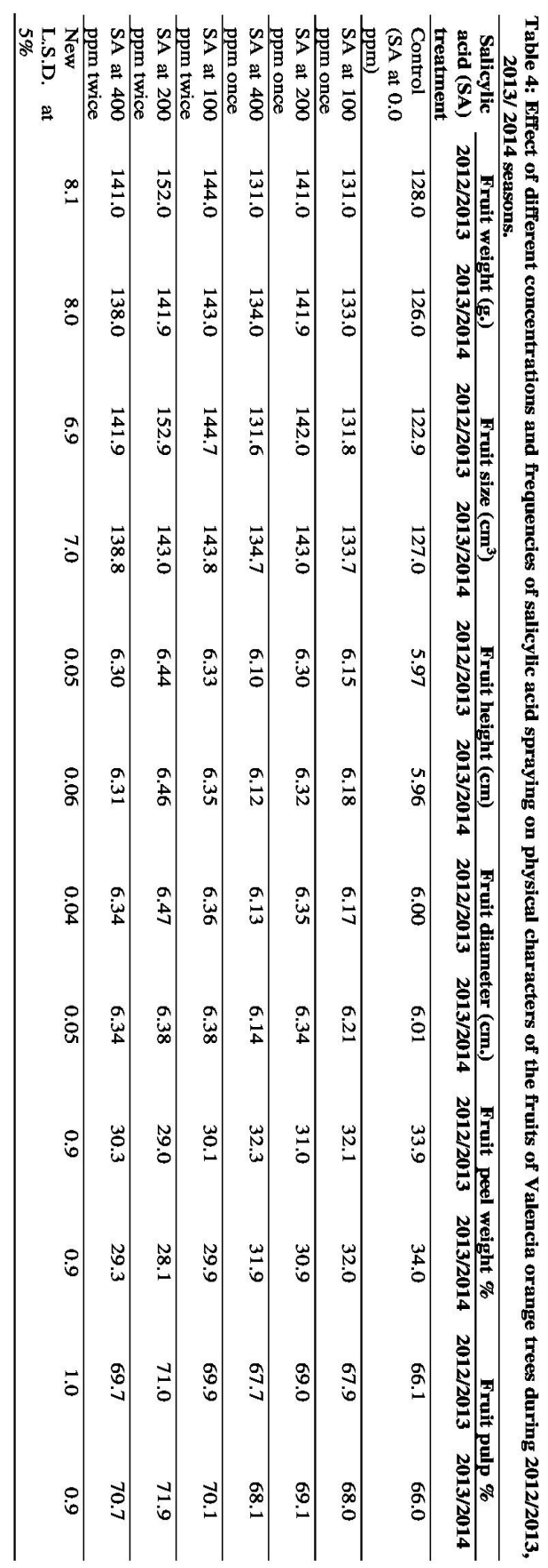




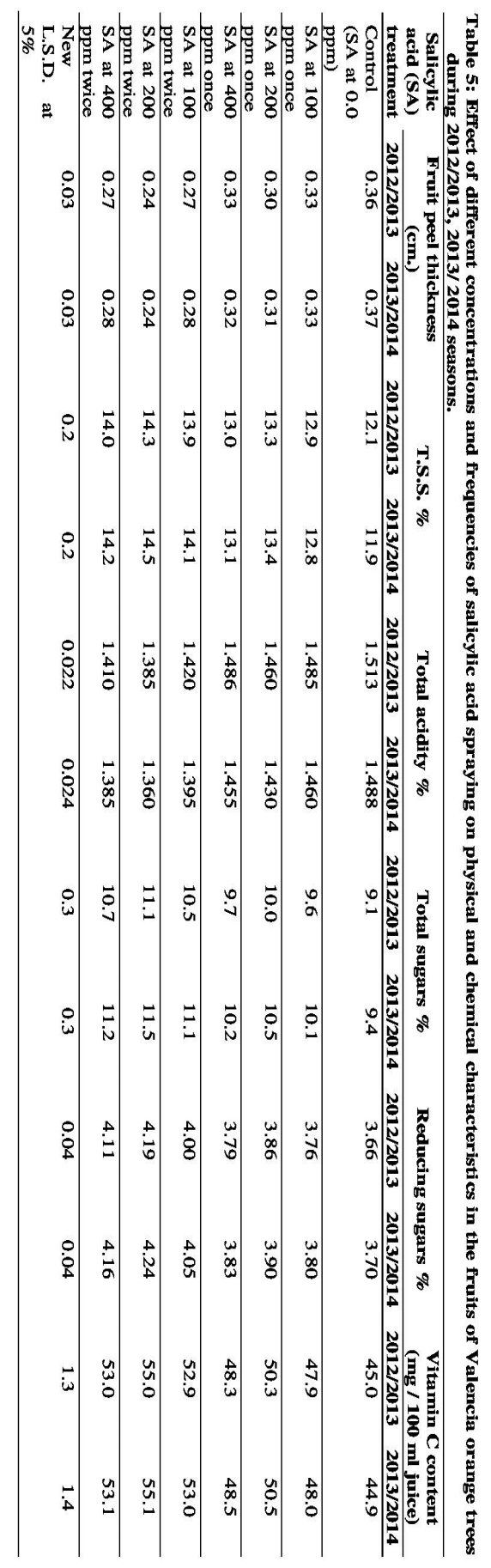


(1.18 and $1.15 \%)$ and the highest June drop (1.1 \& $1.4 \%$ ) during $2013 \% 2014$ seasons, respectively. These results were true during both seasons.

\section{4- Yield/ tree:}

Yield expressed in weight (kg.) and number of fruits / tree as shown in Table (3) was significantly improved owing to using salicylic acid once or twice at 100 to $400 \mathrm{ppm}$ comparing to the check treatment. The promotion on the yield expressed in weight was significantly related to increasing concentrations of salicylic acid from 0.0 to 200 ppm. A significant reduction in the yield expressed in weight and number of fruits/ tree was observed with increasing concentration of salicylic acid form 200 to $400 \mathrm{ppm}$ regardless the number of sprays. Using salicylic acid twice significantly was preferable in improving the yield than using it once. The maximum values of yield $(52.0 \& 52.5 \mathrm{~kg})$ during both seasons, respectively, were recorded on the trees that received two sprays of salicylic acid at $200 \mathrm{ppm}$. The untreated trees produced the minimum values $(36.6 \& 38.0 \mathrm{~kg})$ during both seasons, respectively. The percentages of increase in the yield due to using the promised treatment over the check treatment reached 34.7 and $38.2 \%$ during 2012/2013 and 2013/2014 seasons, respectively. These results were true during both seasons.

\section{5- Fruit quality:}

It is clear from the data in Tables $(4 \& 5)$ that treating Valencia orange trees once or twice with salicylic acid at 100 to 400 significantly was very effective in improving fruit quality in terms of increasing weight, size, height and diameter of fruit , pulp $\%$, T.S.S. $\%$, total and reducing sugars $\%$ and vitamin $\mathrm{C}$ content and reducing fruit peel weight $\%$, fruit peel thickness and total acidity $\%$ over the control treatment. Increasing concentrations form 200 to $400 \mathrm{ppm}$ regardless the frequencies of application had undesirable effects on fruit quality. The best results were obtained due to carrying out two sprays of salicylic acid when compared with using one spray. Significant differences for all quality parameters were observed among all salicylic acid concentrations. The best results were obtained due to treating the trees twice with salicylic acid at $200 \mathrm{ppm}$. Untreating the trees with salicylic acid gave worst effects on the fruit quality. These results were true during both seasons.

The beneficial effects of salicylic acid on stimulating growth characters might be attributed to its essential roles in enhancing cell division and the biosynthesis of organic foods and plant pigments (Hayat and Ahmed, 2007). The beneficial effects of salicylic acid on plant metabolism and uptake and translocation of nutrients (Ding et al., 2001) could result in enhancing plant pigments and different nutrients. The outstanding positive action of salicylic acid on enhancing $\mathrm{C} / \mathrm{N}$ in favour of enhancing flowering as well as the tolerance of plants to all stresses as well as its effects on reducing June drop could explain its effects on enhancing initial fruit set and fruit retention (Ding and Wang, 2003). The promoting effect of salicylic acid on improving initial fruit set and fruit retention as well as reducing June drop could interprete its positive action on the yield. The promoting effect of salicylic acid on the biosynthesis and translocation of plant pigments and $\mathrm{Mg}$ could explain the positive action of it on fruit quality.

These results are in agreement with those obtained by Ahmed (2011); Abd El- Rahman and El- Masry (2012); Ahmed et al., (2014), (2015a \& b); Omar (2015) and Abd El-Mageed (2015) on different evergreen fruit crops.

\section{CONCLUSION}

The best results with regard to yield and fruit quality of Valencia orange trees were obtained due to treating the trees twice at growth start and again just after fruit set with salicylic acid $200 \mathrm{ppm}$.

\section{REFERENCES}

Abd El- Mageed, M.M.H. (2015). Response of Sakkoti date palms to spraying salicylic acid under Aswan region conditions. M. Sc. Thesis, Fac. of Agric., Minia Univ.. Egypt.

Abd El- Rahman, M.M.A. and El- Masry, S.M.A (2012). Response of Valencia trees to foliar application of some vitamins, salicylic acid and turmeric extract. Minia J. of Agric. Res. Dev. 32 (5): 851-867.

Ahmed, E.F.S (2011). Response of Sakkoti date palms to foliar application of salicylic acid. Minia J. of Res. Dev. 21 (2): 305-316.

Ahmed, F. F and Morsy, M. H. (1999). A new method for measuring leaf area in different fruit species. Minia. J. of Agric .Res. \& Dev.19: 97 - 105.

Ahmed, F.F.; Kamel, M. Kh. and Ibrahim, H.I.M. (2014). The synergistic effect of using plant extracts and salicylic acid on yield and fruit quality of Keitte mango trees. Stem Cell,. 5 (2): 30-39.

Ahmed, F.F.; Ibrahim, I.M. and Abd El- Megeed, M.M.H. (2015a). Response of Sakkoti date palms to spraying salicylic acid. Word Rural Observations. 1(1): 10-20.

Ahmed, F.F.; Mohamed, M.A.; Mohamed, A.Y. and Omar, M.G.G. (2015b). Response of Saidy date palms to some inorganic, organic and biofertilization as well as some antioxidant treatments World Rural Observations 7(2): 126-139.

Association of Official Agricultural Chemists (A.O.A.C.) (2000). Official Methods of Analysis (A.O.A.C), $12^{\text {th }}$ ed., Benjamin Franklin Station, Washington D.C., U.S.A. pp. 490-510. 
Ding, C.K. and Wang, C.Y. (2003). The dual effects of methyl salicylate on ripening and expression of ethylene biosynthetic genes in tomato fruit. Plant Science, 164: 589-596.

Ding, C.K.; Wang, C.Y.; Gross, K.C. \& Smith, D.L. (2001). Reduction of chilling injury and transcript accumulation of heat shock protein genes in tomatoes by methyl jasmonate and methyle salicylate. Plant Science. 161, 11531159.

Hayat, S. and Ahmad, A. (2007). Salicylic Acid, A Plant Hormone Chapter 9. Date, J.F., Capelli, $\mathrm{N}$ and Dan- Breusegem. The interplay between salicylic acid and reactive oxygen species during cell death in plants. Springer p. 247-276.

Hiscox, A. and Isralstam B. (1979). Method for the extraction of chlorophylls from leaf tissue without maceration. Can. J. Bot. 57: 13321334.
Lane, J. H. and Eynon, L. (1965). Determination of reducing sugars by means of Fehlings solution with methylene blue as indicator A.O.AC. Washington D.C.U.S.A. pp. 490510.

Mead, R.; Currnow, R. N. and Harted, A. M. (1993). Statistical. Methods in Agricultural and Experimental Biology. $2^{\text {nd }}$ ed Hall, London pp. 10-20.

Omar, M. G.G. (2015). Response of Saidy date palms growing under new Valley conditions to some inorganic, organic and biofertilization as well as some antioxidant treatments. Ph. D. Thesis, Fac. of Agric. Minia Univ., Egypt.

Summer, M.E. (1985). Diagnosis and Recommendation Integrated system (DRIS) as a guide to orchard fertilization. Hort. Abst. 55(8): 7502.

Wilde, S. A.; Corey, R. B.; Lyer, I. G. and Voigt, G. K. (1985). Soil and Plant Analysis for Tree Culture. $3^{\text {rd }}$ Oxford \& IBH publishing Co., New Delhi, pp. $1-218$.

\title{
الملخص العزبى
}

\author{
تأثير رش حامض السلسليك على الاثمار فى اشجار البرتقال الفالنشبا \\ رندا السيد يونس هباس$$
\text { قسم بحوث المو الح- معهد بحوث البساتين - مركز البحوث الزر اعية- الجيزة- مصر }
$$ \\ تم در اسة درجة استجابة صفات النمو الخضرى و الحالة الغذائية للثجرة و النسبة المئوية لعقد الثمـــار المبــدئى

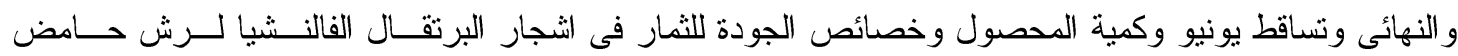 \\ السلسيليك بتزكيز ما بين صفر الى + . جـ جزء فى المليون مرة واحدة فى بداية النمو الخضرى ومرتان فــى بدايــة

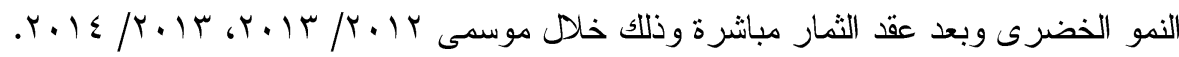 \\ كان هناك تحسن واضح فى جميع صفات النمو الخضرى وصبغات الورقة و عناصر النتـروجين و الفوســفور \\ و البوتاسيوم و الماغنسيوم و الكالسيوم في الورقة و النسبة المئوية للعقد المبدئى و النهائى وكمية المحصول وخــصائص \\ الجودة للثمار عند رش حامض السلسليك بتركيز من . . الى . . .ع جزء فى المليون مرة او مرتان وذللك بالمقارنة \\ بمعاملة الكونترول. وكان هناك انخفاض و اضح فى جميع المقاييس عند استخدام حامض السلسليك بتركيز . . ؛ جزء \\ فى المليون وذلك بالمقارنة باستخدام حامض السلسليك بتركيز من · . 1 اللى . . ب جزء فى المليون وكان اسـتخدام \\ رشتين من حامض السلسليك افضل من استخدام رشة واحدة فى هذا الصدد. \\ إن رش اشجار البرتقال الفالنشيا مرتان فى بداية النمو وبعد عقد الثمار مباشرة بحـــامض الســــليك بتركيـز \\ . . . جزء فى المليون يكون فعالا لتحسين كمية المحصول وخصائص الجودة للثمار . \\ الكلمات الالة: حامض السلسليك - النمو - الاثمار - اشجار البرثقال الفالنشيا.
}

